\title{
国立研究開発法人に打ける 研究健全化の取組み:理化学研究所の事侧
}

有信睦弘

\section{初めに}

理化学研究所は日本で唯一の自然科学の総合 研究所として広範な分野で研究を進めている。 1917 年に財団法人として設立され、株式会社、 特殊法人と経営の在り方が変わる中で、2003年 に文部科学省所轄の独立行政法人、2015年に独 立行政法人の 1 形態である国立研究開発法人と して、我が国の科学技術政策の中で、特に基礎 科学分野の研究を担ってきた。

研究の健全性 research integrityは基本的に は研究を実施する研究者によって維持されるも のである。過去のいくつかの研究不正と言われ ているものへの対応を見ると、特に基礎研究分 野においては、研究上の不正は不正を行った個 人が特殊であるか、特殊な条件のもとで行われ たと考える傾向があったように見える。基礎研 究の分野では不正が具体的な経済的利益に直結 しないと考えられてきたからである。しかし、 科学技術基本計画に沿った公的研究教育機関に 対する研究開発費の大幅な増加と、結果として 増加した研究者達に対する雇用の手当てが十分 に考えられていなかったことに起因する不安定 な雇用形態の中で、実際に研究を担う研究者が 優位なポジションの確保や獲得等の重圧に曝さ れるケースが増えている。併せて、研究開発費 の大幅な増加の結果、研究組織は公費としての 研究費の投入結果に対する説明責任をより厳し く問われるようになっていることも自覚しなけ
ればならない。

理化学研究所においては研究健全性の確保 のために「科学研究上の不正行為の防止等に関 する規程」を定め、内部告発等についても通報 制度を整備しつつ対応してきた。それにも拘ら ず、所謂STAP研究論文に係る不正事案を防止 できず、発生した事態に対応するために多くの 労力と資源が費やされた。本稿ではまず、この 問題に対する経緯を述べることによって、研究 不正に対する理化学研究所の具体的な対応例を 示し、次に研究の健全性を確保するための施策、 その日常的な実行と仕組み、最後に、今後の課 題と考えられることを述べることとしたい。

\section{1．経緯・概要}

理化学研究所（以下理研という）の研究者か ら出された Nature vol. 505 641-647, 2014 （以下 「Article」という)、およびNature vol. 505 676680, 2014 (以下「Letter」という) について、 2014年1月 28 日、理研が成果を発表した。同年 2 月 13 日、Article及び中心研究者が過去に発表 した論文の図版について、外部有識者から理研 職員が疑義の指摘を受けた。研究所は同日より 「科学研究上の不正行為の防止等に関する規程」 (平成 24 年規程第 61 号）（以下「規程」という） に基づく予備調査を開始し、同月 17 日、本調 査の実施を決定。2月18日に外部専門家を含む 「研究論文の疑義に関する調査委員会」を設置 
した。調査項目及び対象者は省略するが、極め て詳細な調査が行われたと考えている。調査の ポイントは単純な不注意やミスを超えて不正が 行われたかどうかという点であった。結果、論 文中の図に改竄と捏造が行われたこと、またこ れらの行為は研究者個人によるものであること が認定され、指導的立場にあった人たちの一部 は、不正への関与はなかったものの、指導上の 責任が重大であると判断された。理研は 3 月 31 日に同調査委員会より調査結果の報告を受け、 不服申立てに対する同委員会の審査を経て同年 5 月 8 日、不正行為が認定された研究者に対し てArticleの取り下げ勧告を行った。

5月 10 日、著者の一人から研究所に、Letter 論文に揭載された図版にも誤りがあるとの報告 とともに、著者間で対応を検討したいとの意向 が示されたため、理研は、著者らの自律的な対 応を見守ることとした。6月中旬以降、著者ら により Nature 誌に対して取り下げの申出がな され、同年7月 2 日 Article、Letterともに取り 下げられた。

理研は、研究不正の再発防止への取組みを進 めるために、同年4月1日、理事長を本部長と する「研究不正再発防止改革推進本部」を設置、 さらに4月 4 日に外部有識者からなる「研究不 正再発防止改革委員会」を設置した。同年 6 月 12 日には同委員から、多くの疑義や不適切な研 究行為などを含めた全体像をとらえて、研究不 正防止のための取組みを根本から見直し、実効

\section{PROFILE}

有信睦弘

(ありのぶ むつひろ)

日本学術会議第三部会員、理化学研

究所理事

専門: 工学・機械工学
性のある対策を実施することが提言された。ま た、共著者や監督責任者、所属長、理事等の役 割や責任、組織運営やガバナンスについての検 討が重要であるとの指摘もなされている。

一方、研究不正の調査とは別に、論文の作成 経緯や過程での問題点の検証を目的とした自己 点検検証委員会を、当該研究者の所属する発生・ 再生科学総合研究センター（以下センターとい う）に設置。6月10日の同委員会による報告で は、STAP問題が発生した原因は当該研究の直 接の関係者だけではなく、研究者の採用と管理 を担当したセンター長、センター運営会議、人 事委員会等の運営担当者にもあるとされた。更 に、報道発表の仕方や、論文不正の可能性が指 摘されたのちの対応等が、この問題を一層複雑 にした要因であるとも指摘している。

STAP細胞研究関連試料の登録公開デー夕に 基づく遺伝子解析結果やSTAP研究関連試料の 解析結果を踏まえて、規程に基づく本調査の必 要性を検討するため、同年 6 月 30 日より予備調 査が開始された。予備調査において確認された 複数の疑義について、理研は本調査の実施が必 要と判断し、平成 26 年 9 月 3 日、委員長はじめ 
委員全員が外部専門家から構成される「研究論 文に関する調査委員会」を設置した。

同委員会による詳細な検証が行われた結果、 論文にかかるSTAP現象はすべて ES細胞の混 入に由来する、あるいはそれで説明できること、 そして主張の根拠となるべき多くの実験記録が 存在しないこと、新たに 2 件の不正行為があっ たこと等が明らかとなった。改めて、捏造が認 定されるとともに極めて杜撰なデー夕管理が指 摘されたものである。また、指導者の一人には 重大な過失責任があるとされた。

\section{2. 理研の対応}

理研は 2014年3月 31 日に報告された調査結 果、外部委員会の取りまとめ等を踏まえて8月 に「研究不正再発防止をはじめとする高い規範 の再生のためのアクションプラン」を策定し た。この中で、研究不正再発防止策としては、 研究倫理教育の徹底、若手研究者が能力を発揮 する環境の整備、論文の信頼性を確保する仕組 みの構築、実験データの記録・管理に関する具 体的なシステムの構築を挙げている。既に、管 理職及び常勤職員等に対する研究倫理教育プロ グラムの受講義務付けや、研究倫理教育責任者 の指名とその役割の明確化等、研究不正防止に 対する組織としての対応がとられている。

\section{2-1. ガバナンスの強化}

研究の健全性を確保するための個々の具体的
な方策とは別に、「研究不正再発防止改革委員 会」から指摘された、組織経営やガバナンスの 課題に対応するために、以下の対応を行った。

(1) 研究所のトップマネジメントの機能強 化拉よびリスクマネジメント等経営の重 要事項について審議を行う会議として理 事長および理事 5 名と外部有識者 7 名から 構成される「経営戦略会議」の設置。

(2) 研究所における内部統制及びコンプラ イアンスを統括し、これらに必要な業務 を行う部署としての「研究コンプライア ンス本部」の設置。

(3) 研究コンプライアンス本部長を「研究倫 理教育統括責任者」とし、その下で、倫理 教育の実施、受講管理等を行う「研究倫理 教育責任者」を各研究センター等に配置。

(4) 研究担当理事を補佐する職として、「研 究政策審議役」及び理事長を科学者の立 場から補佐する「理事長補佐役」の設置。

(5)監事機能強化のために監事監査室の設 置。

\section{2-2. 不正の背景となった組織の解体的出直し}

研究不正が行われたセンターについては運営 上の問題に対応するために根本的な見直しを実 施した。主なものは、「発生・再生科学総合研 究センター」から「多細胞システム形成研究セ ンター」へと名称の改称、組織の大幅な縮小再 編、新センター長の採用、運営体制の抜本的改 革等である。 


\section{2-3. 研究不正防止対策}

防止対策として以下の具体的な方策が決めら れた。

(1) 研究倫理教育プログラムCITI Japanの 導入等による研究倫理教育の徹底

(2) 新任の研究室主宰者に複数のメンター を配置する等の若手研究者が能力を発揮 する場の醉成

(3) 論文類似度検索ツールの導入や研究成 果発表時の承認手続きの明確化等の論文 の信頼性確保の仕組みの構築

(4) 実験デー夕の記録・管理に関する具体的 なシステムの構築・運用

\section{2-4. 規程類の整備}

「科学研究上の不正行為の防止等に関する規 程」の改正及び、「研究記録管理規程」「研究 成果発表に関する規程」の制定を行っている。 これらの規程整備のポイントは、

(1) 組織としての責任体制の確立に係るも の：研究コンプライアンス本部長の統括、 研究倫理教育責任者の配置、役割分担の 明確化等

(2) 不正防止の取組み: 研究倫理教育の定期 的履修の義務化、論文類似度検索ツール の運用等

(3) 文部科学省ガイドラインへの準拠：「特 定不正行為」の定義、不正行為の疑いが 指摘された場合の取り扱いの記載、調査 期間の目安の設定、調査委員会の外部有
識者の比率を半数以上とする等

である。また、新たに「研究成果の報道発表 に関する規程」を制定し、広報に関する「研究 不正再発防止改革委員会」の指摘に対応すると 共に、発表に関しての組織的責任を明確にして いる。

\section{2-5. 取組みのチェック機能について}

「研究不正再発防止をはじめとする高い規範 の再生のためのアクションプラン」による取組 みが適切かつ実効性をもって行われているかに ついて審議を行う、外部の有識者 6 名から構成 される「運営・改革モニタリング委員会」を設 置し、アクションプランに沿った改革の実施状 況のモニタリングを続けている。

同委員会により、2015年3月にアクションプ ランに沿った改革が進んでいることが確認さ れ、併せて理研に対して幾つかの提言がなされ た。現在は4月以降の経過についてモニタリン グを続けていただいている。

\section{3. 研究健全性確保のための 施策の具体的な実行状況}

\section{3-1. 日常的な管理運営}

組織としての日常的な実行管理は研究コンプ ライアンス本部を中心に行われている。具体的 には、

(1) 内部統制、リスク管理、科学研究上の不 正行為防止、等に係る規程の実施状況の 
フォロー

(2) 管理者向け、及び非管理者向けのコンプ ライアンスブックの改訂等による研究倫 理教育の意識づけ

(3) 研究倫理プログラムCITI Japanの受講 管理

(4) 公益通報、告発及び相談に係ること

等について、月に2回フォロー結果が研究コ ンプライアンス本部長に報告され、都度必要な 対応がとられるという形でPDCAが回るよう になっている。アクションプランに含まれる、 広報体制の改善や、新任の研究室主宰者へのメ ンター任命など、関連事務部門と連携が必要な ものについては連携を取りながら対応が進めら れている。

このような研究コンプライアンス本部を中 心とした、研究健全性の確保に関する取組みに ついては、内部監查、監事監査によってその適 正性が監査される形でより大きなPDCAが回 る。加えて、外部機関としてのモニタリング委 員会が理研の取組みの適正性をモニタリングす ることになっており、より大きなPDCAが回る 仕組みが構築されている。

\section{3-2. 研究倫理教育責任者の活動}

各研究センターには研究倫理教育責任者が配 置され、研究コンプライアンス本部長が総括責 任者に任命されている。研究倫理責任者につい ては各センター等に推薦を依頼し、任命するこ ととしたが、優れたシニアの研究者が推薦され、
研究倫理教育、研究倫理意識の醸成、デー夕管 理等の具体的な方策への助言等きめ細かい活動 が行われている。

特に難しいのが、研究倫理意識の醸成の確認 である。また、実験ノートやデー夕の保存管理 についてもライフサイエンスから、物理、工学 まで幅広い分野の間で、また、物理分野に限っ ても理論と実験系の間等、様々な考え方や方法 の違いがある。これらの問題点については、任 命から半年たったところで研究室主宰者、研究 倫理教育責任者から実施状況についてアンケー トをとり、その結果に基づいて、倫理教育責任 者と総括責任者の面談による個別課題の検討、 倫理責任者全体会議によるグッドプラクティス の共有等が進められている。

実験ノートやデータの管理保管、類似度 チェックや様々な確認等、研究発表上の手続き や管理は研究者にとっては、初めは煩償な業務 が増えたと感じられるかもしれないが、これら のことが当たり前のこととして日常化すること が重要である。また、研究や研究健全性に関す る議論が日常的にオープンに行われる環境の中 でこそ、研究の健全性が確保される風土が形成 されるので、様々な施策が研究者を委縮させる ことがないように十分に配慮することが必要で ある。

\section{3-3. 研究倫理の意識づけの試み}

研究倫理教育についてはCITI JapanのE ラーニングを進めるとともに、より簡易な教材 
を作成し、CITIの受講者が毎年簡易版を受講 するようにしている。また、科学技術振興機構 にお願いして、研究倫理教材「THE LAB」の 紹介および活用方法のセミナーを開催した。こ の内容は好評で、現在個々人が自修できるよう にしてある。また、各事業所ごとに研究倫理ワー クショップを順次開催している。外国人研究者 も多く、ワークショップは外国人インストラク ターにより英語で進められている。

\section{3-4. 公益通報、相談等}

研究の健全性はオープンな䨌囲気の中で自由 に議論できる環境の中で風土として確立される ことが望ましい。しかし、そのような風土の醉 成には時間がかかる。健全性を損なうような芽 を早期に摘み取るためには内部通報制度や外部 からの通報制度、あるいは個別の相談等に適切 かつ迅速に対応することが必要である。理研で は「公益通報等の適正な処理に関する規程」が 2012年に制定されているが、2014年に新設研 究コンプライアンス本部に空口を置く他、外部 にも通報空口を置くことを規程化した。内部の 空口の他、外部にも直接通報できることが規程 に盛り込まれている。

\section{4. 今後の課題}

日本語では「研究不正」と言われるが、英語 ではResearch Misconductと言われているよう である。また、理研では既述のように研究コン
プライアンス本部という名称の組織が立ち上げ られたが、これも英語ではResearch Integrity と言われることが多いようである。日本語が一 刀両断に不正/不法と決めつけた印象を与える のに対して、英語は、研究不正と言われるもの の様々な原因に対する配慮と従って個々の対応 が想像できるように思える。当然のことなが ら、不正な手段や間違いによって捏造された研 究結果には価值がない。このような研究結果を 公表することは研究者にとっては自殺行為と言 える。それにも拘らず何故ミスコンダクトが起 きるのかという問題の答えを得るのは簡単では ない。

科学者や研究者は社会からは知的な専門家 と思われている。特別の専門的職業に就くもの は、専門性に裏付けられた職業倫理と行動規範 を持っている。患者が医者に身を委ねられるの はこのような背景に基づいている。科学者や研 究者も、その育成過程で倫理観や行動規範を身 に付けることが期待されており、従来は教育課 程や、大学院での研究指導の中で身に付けるよ うになっていた。

一方、科学技術基本法に基づく科学技術基 本計画に沿って、多額の公的な研究開発資金が 重要分野と見なされる領域に投入されるように なった。重要分野は科学技術の国際競争力や日 本の将来にとって重要という観点で定められ、 研究者は研究資金の獲得と国際競争という二重 の競争にさらされることになった。「重要分野」 に投入された多額の研究費はその分野で多数の 
研究者を輩出することになった。しかし、アカ デミアの安定的な職は限られており、日本の将 来に必要な研究は産業化には遠く、産業界にも 十分な雇用吸収力はない。研究者は、先の二重 の競争に加えて安泰な職を確保するための競争 にも曝されることになる。競争の中での研究業 績の評価に当たっては、優れた研究の選別の場 合を除いて、公表論文の数がその指標となりが ちである。

過度の競争環境の中で、研究者には倫理観と 行動規範に基づいて研究の健全性を維持するこ とが求められている。理研では研究者に対する 倫理教育を進めるとともに、理研の研究者・職 員の行動規範を制定した。また、研究者のほぼ 90\%が任期制の研究者であるという雇用形態の 問題に対しては、研究者の流動性の確保という 点で良い面もあるが課題も多い。現在、雇用の 在り方を抜本的に見直す作業を進めているとこ ろである。

また、具体的に施策を実行する際に浮かび 上がる課題もある。例えば、日本学術会議か ら 2015年3月に文部科学省の諮問に対する回答 として「科学研究に扔ける健全性の向上につい て」が出された。この中で「研究データの保存 は原則 10 年とする」とされた。理研で以前に 定めた規程では保存期間を 5 年としており、学 術会議の「原則 10 年」に対する対応の検討を 進めている。デー夕に関しては、分野ごとに取 り扱いや考え方が違うこと、任期制研究者の多 くは 5 年任期であり、デー夕を含む研究結果の
組織帰属の原則と、研究者の権利の問題、保管 キャパシティという現実的問題等、検討課題は 多い。「回答」でもそれぞれの分野の特性に応 じて検討すべきとされており、分野の特性が適 正に判断されることが必要である。

研究の健全性を確保するためには、具体的な 課題に肯定的に対処しつつ、ミスコンダクトの 起きる背景の改善にも取組み、自由に伸び伸び と研究できる風土を醸成していくことが重要で ある。 